\title{
Co-occurrence of Artemisia and Ambrosia pollen seasons against the background of the synoptic situations in Poland
}

\author{
Danuta Stẹpalska $^{1}$ • Dorota Myszkowska ${ }^{2}$ - Leśkiewicz Katarzyna ${ }^{3} \cdot$ Piotrowicz Katarzyna $^{4}$ • \\ Borycka Katarzyna $^{5}$ - Chlopek Kazimiera ${ }^{6}$. Grewling Lukasz ${ }^{7}$ - Kasprzyk Idalia ${ }^{5}$. \\ Majkowska-Wojciechowska Barbara $^{8}$ - Malkiewicz Malgorzata ${ }^{9}$ Nowak Malgorzata ${ }^{7,10}$. \\ Piotrowska-Weryszko Krystyna $^{11} \cdot$ Puc Małgorzata $^{12}$ • Weryszko-Chmielewska Elżbieta ${ }^{13}$
}

Received: 14 December 2015 /Revised: 23 September 2016 / Accepted: 23 September 2016 / Published online: 8 October 2016

(C) The Author(s) 2016. This article is published with open access at Springerlink.com

\begin{abstract}
The Asteraceae family is one of the largest families, comprising 67 genera and 264 species in Poland. However, only a few genera, including Artemisia and Ambrosia are potential allergenic sources. The aim of the study was to estimate how often and to what degree Artemisia and Ambrosia pollen seasons co-occur intensifying human health risk, and how synoptic situations influence frequency of days with high pollen concentrations of both taxa. Artemisia and Ambrosia pollen data were collected, using the volumetric method, at 8 sites in Poland. Daily concentrations of Artemisia pollen equal to 30 grains or more and Ambrosia pollen equal to 10 grains or more were accepted as high values. Concentrations of more than 10 pollen grains were defined as high in the case of Ambrosia because its allergenicity is considered higher. High concentrations were confronted with synoptic situations. Analysis was performed on the basis of two calendars on circulation types of atmosphere in Poland (Niedźwiedź, 2006, 2015). Co-occurrence of Artemisia and Ambrosia pollen seasons is being found most often, when Ambrosia pollen
\end{abstract}

Dorota Myszkowska

dorota.myszkowska@uj.edu.pl

1 Institute of Botany, Jagiellonian University, Kraków, Poland

2 Department of Clinical and Environmental Allergology, Jagiellonian University Medical College, 31-531 Kraków, Śniadeckich 10, Poland

3 Institute of Information and Library Science of the Jagiellonian University, Kraków, Poland

4 Institute of Geography and Spatial Management, Jagiellonian University, Kraków, Poland

5 Department of Environmental Biology, University of Rzeszów, Rzeszów, Poland

6 Faculty of Earth Sciences, University of Silesia, Sosnowiec, Poland season starts in the first half of August. If it happens in the last 10 days of August high pollen concentrations of Artemisia and Ambrosia do not occur at the same days. At three sites (Sosnowiec, Rzeszów, Lublin) high Ambrosia pollen concentrations during the Artemisia pollen season appear more often than in other sites under question. The high Artemisia pollen concentrations occur, when continental or polar maritime old air masses inflow into Poland. The impact of air masses on high Ambrosia pollen concentrations depends on site localizations. It is likely, that in the south-eastern part of Poland high Ambrosia pollen concentrations result from the pollen transport from east-south-south-westerly directions and the local sources. Co-occurrence of both taxa pollen seasons depends on the air masses inflow and appears more often in a southeastern part of Poland.

Keywords Artemisia $\cdot$ Ambrosia $\cdot$ Pollen season co-occurrence $\cdot$ Aerobiological monitoring $\cdot$ Poland

7 Laboratory of Aeropalynology, Faculty of Biology, Adam Mickiewicz University, Poznań, Poland

8 Department of Immunology, Rheumatology and Allergy, Medical University of Łódź, Łódź, Poland

9 Laboratory of Paleobotany, Department of Stratigraphical Geology, University of Wroclaw, Wrocław, Poland

10 Department of Dermatology, University of Medical Sciences, Poznań, Poland

11 Department of General Ecology, University of Life Sciences in Lublin, Lublin, Poland

12 Department of Botany and Nature Conservation, University of Szczecin, Szczecin, Poland

13 Department of Botany, University of Life Sciences in Lublin, Lublin, Poland 


\section{Introduction}

The Asteraceae family is one of the largest families of plants, comprising approximately 1100 genera and 20,000 species including 67 genera and 264 species in Poland. However, only a few genera, including Artemisia (mugwort) and Ambrosia (ragweed) among others, are potential sources of allergenic pollenprovoking allergic rhinitis and conjunctivitis (D'Amato et al. 2007; Gadermaier et al. 2004; Peternel et al. 2008).

The genus of Artemisia comprises about 400 species and is widely distributed in temperate and humid zones of the northern hemisphere and along the Mediterranean basin. The most common Artemisia species in Europe are A. vulgaris L. (mugwort), A. campestris L. and A. absinthium L. (Tutin 1972). Other Artemisia species are also widespread in the central and eastern part of Europe including Poland, Hungary and Bulgaria, e.g.: A. pontica L., A. annua L., A. maritima L. and A. scoparia W. et K. (Soó 1970; Tutin 1972). Artemisia species colonizes disturbed soils in urban and rural habitats, roadside verges, agricultural fields and deserted places (Spieksma et al., 2003). Artemisia vulgaris occurs evenly throughout Poland. Artemisia campestris and A. absinthium have similar distribution to Artemisia vulgaris (Zając and Zając 2001).

The incidence of allergic diseases caused by Artemisia pollen in Europe is being estimated between $3 \%$ and $15 \%$ of pollinosis patients (D'Amato et al. 1998; Stach et al. 2007). It is known that significant cross-reactivity among ragweed species within the Ambrosia genus and also between the major allergens of
Ambrosia and Artemisia appears (Dahl et al., 1999; Jäger, 2000). According to Spieksma (1986), 3-10\% of all all pollen sufferers are allergic to mugwort antigens and simultaneously allergic to ragweed and grass pollen allergens, and the allergens of apple and celery (Hirschwehr et al. 1998). Asero et al. (2006) studying Artemisia and Ambrosia hypersensitivity indicated that only $7 \%$ of mugwort hypersensitive patients were not sensitized to ragweed, whereas $62 \%$ of ragweed hypersensitive patients were not sensitized to mugwort. In Italy the threshold concentration of Artemisia pollen, which reveals clinical symptoms of pollinosis in allergic people, is reported by Voltolini et al. (2000) as $12 \mathrm{PG} / \mathrm{m}^{3}$. In Poland the first symptoms of sensitization to Artemisia pollen emerge when the daily concentration amounts $30 \mathrm{PG} / \mathrm{m}^{3}$. The concentration of $70 \mathrm{PG} / \mathrm{m}^{3}$ provokes intensive symptoms (Rapiejko et al. 2007).

The genus of Ambrosia is composed of about 40 species of which only five have been recorded in Europe: Ambrosia artemisiifolia L. = A. elatior (short or common, annual ragweed), Ambrosia trifida L. (great or giant ragweed), Ambrosia psilostachya Torr. et Grey = A. coronopifolia (perennial ragweed), Ambrosia tenuifolia Sprang. (silver ragweed) (Hansen 1976). However, short ragweed is the most widely spread of all (Járai-Komlódi and Juhász 1993). In Poland, the most frequently found species is Ambrosia artemisiifolia L. Currently this species occurs most commonly in the western and southwestern parts of Poland.

The historical spread of Ambrosia artemisiifolia in Poland is recorded in consecutive time periods (Fig. 1) (Tokarska-
Fig. 1 Recorded history of the spread of Ambrosia artemisiifolia L. in Poland drawn for the consecutive time periods. between 1851 and 1900; between 1901 and 1950; o between 1951 and 2013. Updated map published by TokarskaGuzik et al. (2011), given after Tokarska-Guzik approval

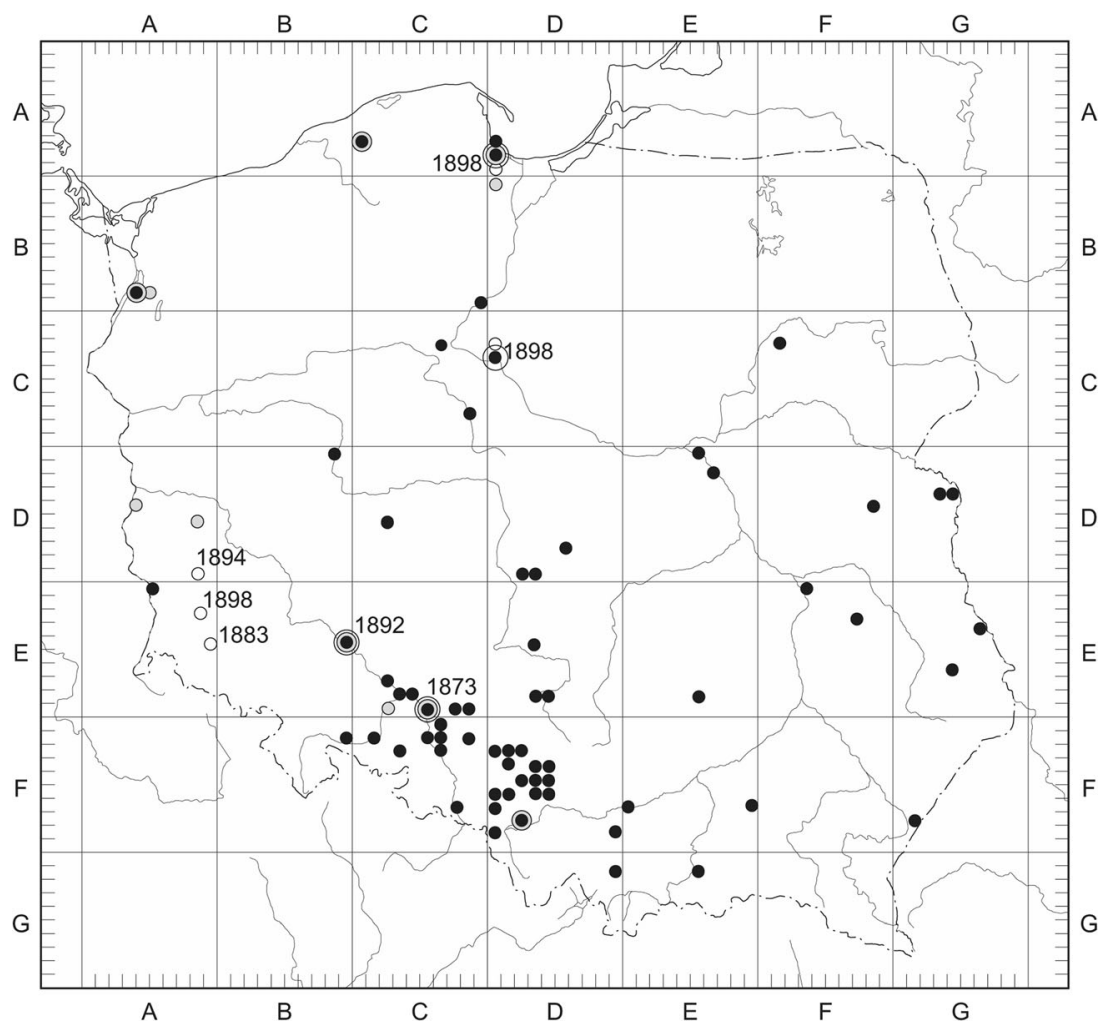


Guzik et al. 2011). Ambrosia maritima L. occurs in the Mediterranean region and is the only native species in Europe. The other four species are native to eastern and central North America from where they were imported as ballast weed to Europe. Ambrosia has evolved in response to a dry climate and open areas. In Europe Ambrosia has already become established mainly due to the large production of seeds that may remain dormant at least 39 years if conditions for germination are unsuitable and allow for its easy and rapid spread (Smith et al. 2013 and references therein). Ambrosia also produces allergenic pollen in enormous amounts: a single plant can produce millions of pollen grains that are small (18$22 \mu \mathrm{m})$ and can easily become airborne. They are considered to be one of the most potent allergens known (Comtois 1998; Weryszko - Chmielewska and Piotrowska 2008). The presence of ragweed in Europe was recorded for the first time at the beginning of the nineteenth century, although it became a real threat after the First World War (Juhász 1998). The places most contaminated with ragweed are Hungary, Croatia and parts of France, but it is also spreading in northern Italy, Switzerland, Austria, the Czech Republic, Slovakia and Bulgaria (Clot 2003; Smith et al. 2013 and references therein). The spread of ragweed seems to be limited by climate even if the human environment would allow its establishment (Comtois 1998; Saar et al. 2000). In areas with maritime climate, ragweed population does not appear to thrive and in Northern Europe the growing season is too short for seed maturation. Populations rely on the introduction of seeds from outside sources (Comtois 1998; Dahl et al. 1999). In Poland common ragweed colonizes cultivated fields and ruderal habitats, grows on disturbed soils, roadsides, near cereal elevators and harbours.

According to clinical experience, ragweed pollen appears to induce asthma approximately twice as often as it occurs in other pollen allergies (Gadermaier et al. 2004). In the area of Milan sensitization rates increased from $20 \%$ to more than $60 \%$ during a five year period (Asero 2002). Research in Austria stated that the higher Ambrosia pollen concentration, the higher the amount of ragweed pollen antibodies in the blood of patients suffering from inhalant allergy (Jäger and Litschauer 1998).

It should be stressed that different studies reported various threshold values of Ambrosia pollen concentrations provoking the first symptoms in sensitized patients. In France the threshold value is 5 pollen grains per $\mathrm{m}^{3}\left(\mathrm{PG} / \mathrm{m}^{3}\right.$ ) (Dechamp et al. 1997) or $13 \mathrm{PG} / \mathrm{m}^{3}$ (Laaidi and Laaidi 1999), in Canada 5 PG/ $\mathrm{m}^{3}$ (Comtois and Gagnon 1998), in Austria 20 PG/m³ (Jäger 1998), in Hungary 30 PG/m³ (Makra et al. 2005).

A knowledge that Artemisia and Ambrosia pollen seasons often overlap, provides information for estimating clinical and prophylactic aspects relating to cross-reactivity and co-sensitization. Studies performed hitherto discussed pollen seasons of these taxa separately, therefore the aim of our study was to estimate how often and to what degree Artemisia and Ambrosia pollen seasons co-occur and potentially intensify the risk to human health at eight selected sites in Poland, and to estimate the impact of specific synoptic situations on Ambrosia and Artemisia pollen concentrations.

\section{Materials and methods}

\section{Study sites}

Ambrosia and Artemisia pollen concentrations were analysed from eight selected sites in Poland (Szczecin, Poznań, Wrocław, Łódź, Sosnowiec, Kraków, Rzeszów, Lublin) (Fig. 2, Table 1). Poland is most frequently influenced by the polar-maritime $(\mathrm{Pm})$ air masses originating from over the Northern Atlantic that bring thaw, an increase in cloudiness and snow in winter, and as well as chilling, an increase in cloudiness and rainfall in summer. The second most frequent air masses influencing Poland are polar-continental air masses (PPk), that bring warm, sunny and dry weather in summer and frosty weather in winter. The inflow of other air masses (arctic and tropical) is very seldom about $2-4 \%$ of days during a year. The highest rainfall level is recorded in summer (June, July and August). In the annual cycle about $40 \%$ of rain falls in these months (Dynowska 1991). According to Paszyński and Niedźwiedź (1991) the atmospheric circulation influences decisively climate in Poland. It causes the increase in continental features of climate in the eastern part of the country, and great variability of weather in short time periods. Therefore the climate in Poland is defined as transitional climate (Kożuchowski, 1999).

\section{Aerobiological data}

The shortest aerobiological records used in our study were in Łódź (10 years) and the longest in Kraków (21 years). The aerobiological measurements were performed using volumetric spore traps of the Hirst design (Hirst 1952). All the traps were installed on roof tops at different heights above ground as seen in Table 1. The different sampling heights depended on the availability of buildings, where traps could be placed. Air was sucked into the trap at rate of $101 / \mathrm{min}$ through a $2 \mathrm{~mm} \times 14 \mathrm{~mm}$ orifice flowing over a rotating drum that moved at $2 \mathrm{~mm} / \mathrm{h}$ and which was coated with an adhesive, transparent tape. Pollen grains were sampled continuously. The tape used for catching pollen grains was replaced every week at the same day and cut into segments corresponding to $24 \mathrm{~h}$ periods. Segments were scanned and counted using a light microscope at $400 \mathrm{x}$ magnification.

Daily average pollen concentrations are expressed as the number of pollen grains per cubic meter of air $\left(\mathrm{PG} / \mathrm{m}^{3}\right)$. To define the start, the end and the duration of the season the $90 \%$ method was applied to eliminate long tails of low values at the start and the end of the seasons that could distort the limits 
Fig. 2 Map of Poland showing the monitoring sites according to regions classified by Niedźwiedź (2006). Two regions: southern and southeastern were marked with black, bold line as regions where air circulations, air masses and atmospheric fronts were classified (Niedźwiedź 2015)

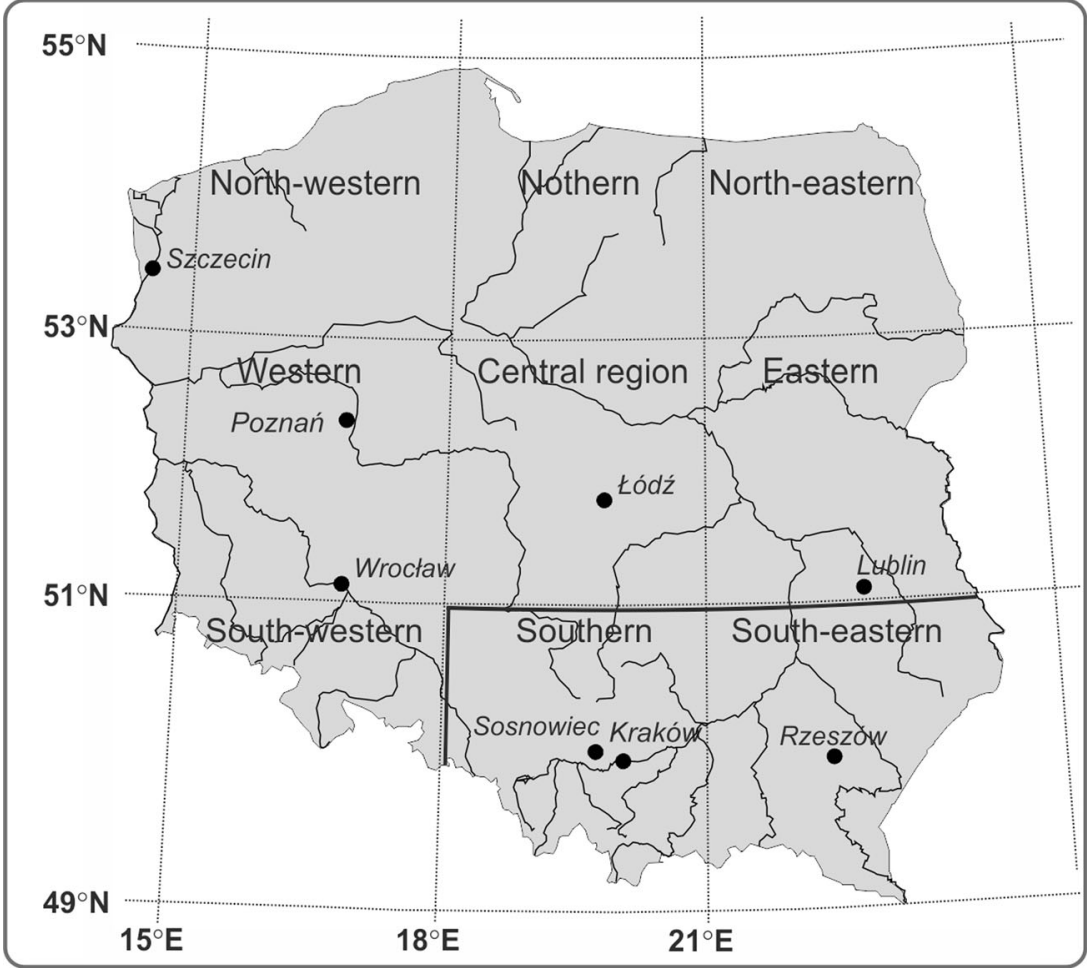

of the seasons. The start of the season was defined as the date when $5 \%$ of the seasonal cumulative spore count was trapped and the end of the season as the date when $95 \%$ of the seasonal cumulative spore count was reached (Nilsson and Persson 1981). To compare the pollen concentrations over the studied years, a Seasonal Pollen Index (SPI) was calculated as the sum of the daily pollen counts in a given season. Because of the high allergenicity of Ambrosia pollen and as airborne pollen concentrations at some sampling sites sometimes marginally exceeded 10 grains per cubic meter of air, we accepted the value of 10 pollen grains $\mathrm{m}^{-3}$ as the threshold for 'high' concentration.

\section{Meteorological data}

The influence of synoptic situations on Artemisia and Ambrosia pollen concentrations in the air was examined on the basis of two calendars on circulation types of atmosphere in Poland (Niedźwiedź 2006, 2015).

The type of the synoptic situation, air masses and atmospheric front in a given day was defined (http://klimat.wnoz. us.edu.pl). Classification by Niedźwiedź (2015) for the southern part of Poland could have been applied for the region within coordinates of $49-51^{\circ} \mathrm{N}$ and $18-25^{\circ} \mathrm{E}$ (Niedźwiedź 2015) (Fig. 2). For the remaining four sites, beyond these limits, other classification also by Niedźwiedź (2006) was used for 9 regions (Fig. 2). Unfortunately this classification was not available before 2001 and comprises only the type of air circulation without air masses and atmospheric fronts. According to this classification Łódź is situated in the central region, Wrocław and Poznań in the western region, and Szczecin in the north-western regions. The symbols of synoptic situation types are the same in both classifications (Table 2).
Table 1 Some information on study sites, including geographical location (coordinates, height above sea level and height above ground level) and the study period

\begin{tabular}{llllll}
\hline Study site & Longitude (E) & Latitude $(\mathrm{N})$ & Altitude a.s.l. (m) & Altitude a.g.l. (m) & Study period \\
\hline Szczecin & $14^{\circ} 33^{\prime}$ & $53^{\circ} 26^{\prime}$ & 52 & 21 & $2000-2012(13$ yrs $)$ \\
Poznań & $16^{\circ} 53^{\prime}$ & $52^{\circ} 24^{\prime}$ & $65-92$ & 53 & $1996-2012(17 \mathrm{yrs})$ \\
Wrocław & $17^{\circ} 01^{\prime}$ & $51^{\circ} 06^{\prime}$ & $105-155$ & 20 & $2002-2012(11 \mathrm{yrs})$ \\
Łódź & $19^{\circ} 28^{\prime}$ & $51^{\circ} 47^{\prime}$ & 150 & 15 & $2003-2012(10 \mathrm{yrs})$ \\
Sosnowiec & $19^{\circ} 08^{\prime}$ & $50^{\circ} 17^{\prime}$ & 263 & 20 & $1998-2012(15 \mathrm{yrs})$ \\
Kraków & $19^{\circ} 59^{\prime}$ & $50^{\circ} 04^{\prime}$ & 220 & 20 & $1992-2012(21 \mathrm{yrs})$ \\
Rzeszów & $22^{\circ} 02^{\prime}$ & $50^{\circ} 01^{\prime}$ & $200-215$ & 12 & $1997-2012(16 \mathrm{yrs})$ \\
Lublin & $22^{\circ} 32^{\prime}$ & $51^{\circ} 14^{\prime}$ & 197 & 18 & $2001-2012(12 \mathrm{yrs})$ \\
\hline
\end{tabular}


Table 2 Synoptic situations, air masses and atmospheric fronts (according to T. Niedźwiedź catalogue, 2014)

\begin{tabular}{ll}
\hline Symbols & Circulation types \\
\hline $\mathrm{E}+\mathrm{SEa}$ & Anticyclonic situation with an advection of air masses from East and South-East \\
$\mathrm{Ca}+\mathrm{Ka}$ & Central anticyclonic situation, anticyclonic wedge \\
$\mathrm{Cc}+\mathrm{Bc}$ & Central cyclonic situation, through of low pressure \\
$\mathrm{S}+\mathrm{SWc}$ & Cyclonic situation with an advection of air masses from South and South-West \\
$\mathrm{S}+\mathrm{SWa}$ & Anticyclonic situation with an advection of air masses from South and South-West \\
$\mathrm{E}+\mathrm{SEc}$ & Cyclonic situation with an advection of air masses from East and South-East \\
$\mathrm{W}+\mathrm{NWc}$ & Cyclonic situation with an advection of air masses from West and North-West \\
$\mathrm{W}+\mathrm{NWa}$ & Anticyclonic situation with an advection of air masses from West and North-West \\
$\mathrm{N}+\mathrm{NEa}$ & Anticyclonic situation with an advection of air masses from North and North-East \\
$\mathrm{N}+\mathrm{NEc}$ & Cyclonic situation with an advection of air masses from North and North-East \\
$\mathrm{x}$ & Unclassified situation \\
& Air masses \\
$\mathrm{PPk}$ & Polar continental \\
$\mathrm{PPms}$ & Polar maritime old (transformed) \\
$\mathrm{PPmc}$ & Polar maritime warm \\
$\mathrm{PPm}$ & Polar maritime (fresh) \\
$\mathrm{rmp}$ & Various air masses in day \\
$\mathrm{PZ}$ & Tropical air masses \\
$\mathrm{PA}$ & Arctic air masses \\
$\mathrm{c}$ & Atmospheric fronts \\
$\mathrm{z}$ & Day without front \\
$\mathrm{z}$ & Cold front \\
$\mathrm{r}$ & Warm front \\
\hline & Stationary front \\
Several various fronts in day \\
Occluded front (occlusion)
\end{tabular}

Detailed analysis on the influence of synoptic situations on Ambrosia pollen concentrations in the southern part of Poland was achieved by using regressive trees (C\&RT). It was therefore possible to define circulation types, air masses and atmospheric fronts, which favour high concentrations. The occurrence of these synoptic situations in the last phase of the Artemisia pollen season favours overlapping of Artemisia and Ambrosia pollen seasons. This method allows the exploration of a great number of data, to define a set of synoptic parameters that determine the division of a dependent variable (daily concentration of Ambrosia pollen) into separable subsets of differentiation.

\section{Results}

\section{Descriptive statistics of pollen seasons}

The season start dates and the peak concentration exhibit low variability for both taxa at all the sites, but there are lower coefficients for Artemisia which means that the season start of Ambrosia is more variable from year to year. The highest coefficients of variability for Artemisia occur for days with $\mathrm{PG} / \mathrm{m}^{3} \geq 30(20.2 \%-75.0 \%)$ and for Ambrosia it occurs for days with $\mathrm{PG} / \mathrm{m}^{3} \geq 10(39.0 \%-92.0 \%)$ (Table 3$)$. The Kruskal-Wallis test revealed that start dates of the Ambrosia pollen season and their duration do not differ among sites $(p>0.05)$. In the case of Artemisia, there are statistically significant differences among sites (Table 3).

\section{Overlapping of pollen seasons of both taxa}

The Artemisia pollen seasons most often begin, in the second half of July at all the sites and start dates fluctuate in relatively small ranges from year to year. The most stable start dates of the Artemisia pollen season were recorded in Rzeszów ( \pm 7 days) and the most variable in Lódź ( \pm 18 days) (Fig. 3). The beginning of Ambrosia pollen seasons is much more variable from year to year. It most often falls in the second decade of August although the earliest start could have been in the middle of July (Łódź), and the latest in first days of September (Poznań, Sosnowiec, Kraków). Start dates of the Ambrosia 
Table 3 Artemisia and Ambrosia pollen season characteristics in the selected cities in Poland. The descriptive statistics were calculated on the basis of data series presented in Table 1 in a given city. The coefficient of variability $(V \%)$ was calculated on the basis of not rounded values, the values of arithmetic mean $(x)$ and standard deviation $(s)$ are expressed as integers. At the bottom of the table the results of Kruskal-Wallis test

\begin{tabular}{|c|c|c|c|c|c|c|c|}
\hline \multirow[t]{2}{*}{ Study site } & \multirow{2}{*}{$\begin{array}{l}\text { Statistics/ } \\
\text { season } \\
\text { characteristics }\end{array}$} & \multicolumn{3}{|l|}{ Artemisia } & \multicolumn{3}{|l|}{ Ambrosia } \\
\hline & & $\begin{array}{l}\text { Season } \\
\operatorname{start}^{1}\end{array}$ & $\begin{array}{l}\text { Season } \\
\text { duration }^{2}\end{array}$ & $\begin{array}{l}\text { Days with } \\
\mathrm{PG} / \mathrm{m}^{3} \geq 30^{2}\end{array}$ & $\begin{array}{l}\text { Season } \\
\text { start }^{1}\end{array}$ & $\begin{array}{l}\text { Season } \\
\text { duration }^{2}\end{array}$ & $\begin{array}{l}\text { Days with } \\
\mathrm{PG} / \mathrm{m}^{3} \geq 10^{2}\end{array}$ \\
\hline \multirow[t]{3}{*}{ Szczecin } & $x$ & $18-07$ & 40 & 9 & $22-08$ & 29 & 2 \\
\hline & $s$ & 11 & 11 & 6 & 6 & 15 & 2 \\
\hline & $V \%$ & 5.5 & 27.7 & 67.5 & 2.6 & 51.3 & 88.3 \\
\hline \multirow[t]{3}{*}{ Poznań } & $x$ & $25-07$ & 32 & 13 & $19-08$ & 30 & 2 \\
\hline & $s$ & 4 & 12 & 7 & 8 & 12 & 2 \\
\hline & $V \%$ & 2.1 & 37.2 & 52.0 & 3.5 & 41.9 & 159.5 \\
\hline \multirow[t]{3}{*}{ Wrocław } & $x$ & $27-07$ & 28 & 13 & $18-09$ & 31 & 3 \\
\hline & $s$ & 3 & 8 & 5 & 13 & 16 & 2 \\
\hline & $V \%$ & 1.5 & 28.7 & 36.2 & 5.6 & 52.8 & 78.8 \\
\hline \multirow[t]{3}{*}{ Łódź } & $x$ & $20-07$ & 39 & 9 & $14-08$ & 35 & 3 \\
\hline & $s$ & 5 & 9 & 6 & 6 & 8 & 2 \\
\hline & $V \%$ & 2.7 & 22.0 & 72.3 & 2.4 & 23.3 & 147.7 \\
\hline \multirow[t]{3}{*}{ Sosnowiec } & $x$ & $25-07$ & 38 & 26 & $17-08$ & 37 & 7 \\
\hline & $s$ & 4 & 14 & 9 & 8 & 14 & 3 \\
\hline & $V \%$ & 1.8 & 35.9 & 64.0 & 3.4 & 38.1 & 49.1 \\
\hline \multirow[t]{3}{*}{ Kraków } & $x$ & $26-07$ & 32 & 7 & $15-08$ & 32 & 3 \\
\hline & $s$ & 3 & 13 & 5 & 12 & 15 & 3 \\
\hline & $V \%$ & 1.7 & 42.4 & 75.0 & 5.2 & 46.8 & 95.9 \\
\hline \multirow[t]{3}{*}{ Rzeszów } & $x$ & $29-07$ & 34 & 7 & $17-08$ & 27 & 7 \\
\hline & $s$ & 3 & 14 & 5 & 5 & 13 & 3 \\
\hline & $V \%$ & 1.2 & 40.5 & 67.5 & 2.1 & 46.2 & 41.1 \\
\hline \multirow[t]{3}{*}{ Lublin } & $x$ & $23-07$ & 41 & 20 & $17-08$ & 38 & 6 \\
\hline & $s$ & 4 & 13 & 4 & 6 & 14 & 2 \\
\hline & $V \%$ & 1.8 & 31.5 & 20.2 & 2.8 & 35.5 & 42.0 \\
\hline \multicolumn{2}{|c|}{ Kruskal-Wallis test } & $p<0.01$ & $\mathrm{p}<0.01$ & $\mathrm{p}<0.01$ & $p=0.18$ & $p=0.38$ & $\mathrm{p}<0.01$ \\
\hline
\end{tabular}

Season characteristics were calculated using the $90 \%$ method; $x$ - arithmetic mean; $s$ - standard deviation; V\% coefficient of variation

${ }^{1}$ date; ${ }^{2}$ number of days pollen season varied the least in Szczecin, Rzeszów and Lublin and varied the most in Kraków and Wrocław.

The Spearman's rank correlation test revealed that there were no statistically significant correlations between start dates of Artemisia and Ambrosia pollen seasons. It is likely, that the beginning of the Ambrosia pollen season is associated with inflow of air masses. This is confirmed by synchronization of pollen season start dates at three sites in southern Poland (Sosnowiec, Rzeszów, Lublin). The correlation coefficient between the start dates of Ambrosia pollen season at these sites is over 0.88 (Fig. 4).

The end of Artemisia and Ambrosia pollen seasons varied greatly In case of Artemisia the difference between the earliest and the latest end dates at all the sites was from 27 days in Łódź to 54 days in Szczecin and for Ambrosia it was from 20 days in Wrocław to 49 days in Szczecin (Fig. 3). Analysis revealed that the Artemisia pollen season usually started between 19 and 25 days before the beginning of the Ambrosia pollen season at the majority of sites. Figure 3 demonstrates that pollen seasons of both taxa could overlap at all sites although not every year. The values present in Fig. 3: (a) percentage of days in the Ambrosia pollen season overlapping the Artemisia pollen season, (b) number of overlapping days, (c) average number of overlapping days with high concentrations of both taxa.

Time series of high Artemisia pollen concentrations ( $\geq 30$ grains) and high Ambrosia pollen concentrations ( $\geq 10$ grains) presented in Fig. 5 show that the cooccurrence of high daily pollen concentrations of these taxa (single days or series of 2-4 days) most often occur in Sosnowiec and Lublin, and sporadically in Wrocław and Kraków. High daily Artemisia and 

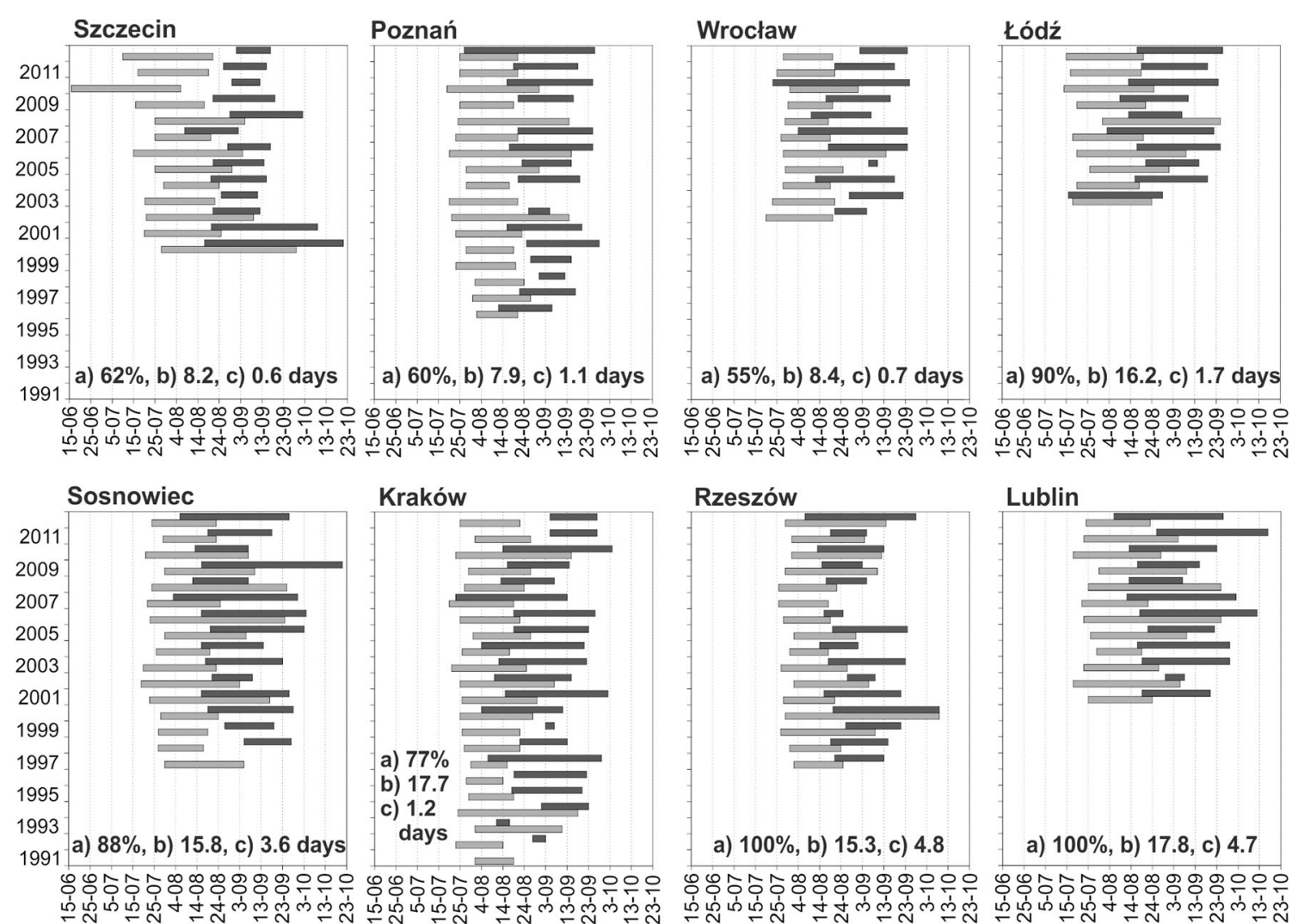

Rzeszów

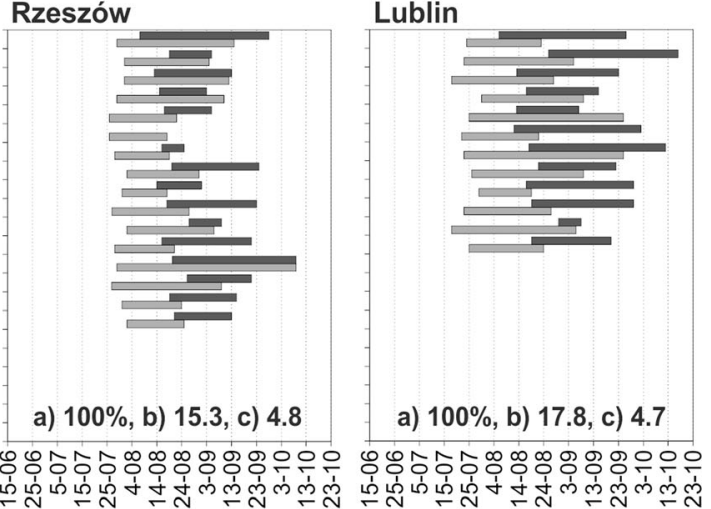

\section{a), b), c) - explanations in text}

Fig. 3 Start, end and duration of Artemisia and Ambrosia pollen seasons in given monitoring sites. a) percentage of days in the Ambrosia pollen seasons overlapping the Artemisia pollen seasons, b) number of

Ambrosia pollen concentrations on these days could be a threat to allergic population. Such co-occurrence

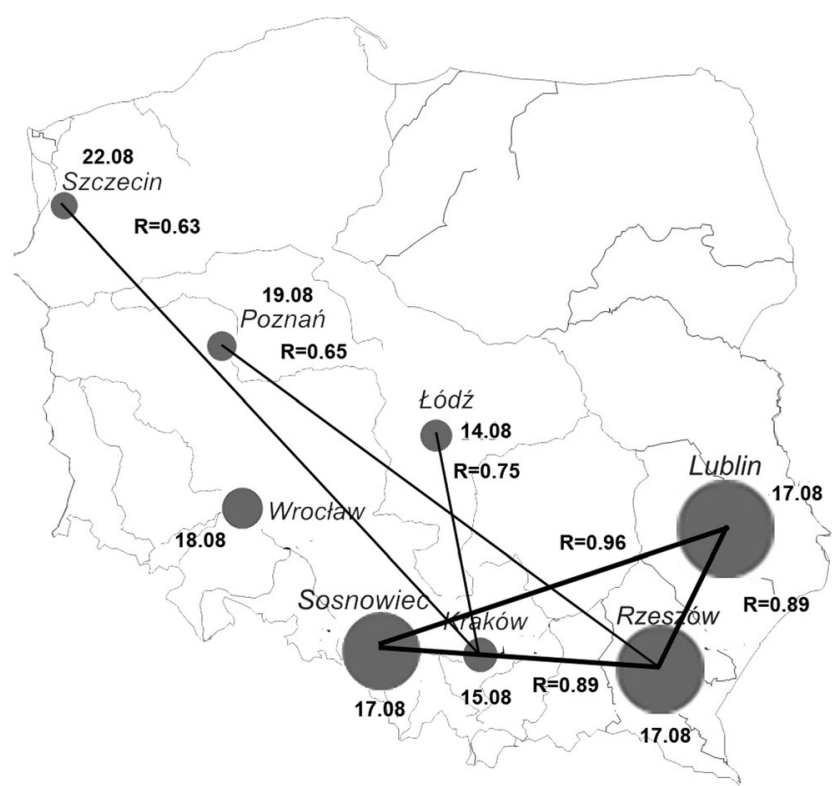

Fig. 4 Selected characteristics of the Ambrosia pollen season: average date of the season start, average SPI (the bigger the circle the higher the $\mathrm{SPI}$ ), correlation coefficient (R) between dates of season starts

\section{- Ambrosia}

overlapping days, c) average number of overlapping days with high pollen concentrations of both taxa

usually happens in August when the Ambrosia pollen season starts in the first half of August (2008). If the Ambrosia pollen season begins a little bit later, in the third decade of August, high pollen concentrations of Artemisia and Ambrosia do not occur on the same days (2011).

\section{Days with different ambrosia t pollen concentrations during the Artemisia pollen seasons}

There are situations during Artemisia and Ambrosia pollen seasons when seasons of both taxa do not overlap at all. There are also situations when days with Ambrosia pollen grains equal to $10 \mathrm{PG} / \mathrm{m}^{3}$ and over $10 \mathrm{PG} / \mathrm{m}^{3}$ co-occur with the Artemisia pollen season. Days with Ambrosia pollen grains below $10 \mathrm{PG} / \mathrm{m}^{3}$ also show up, overlapping the Artemisia pollen season (Fig. 6). Looking at all sites, and assuming that the whole circle is the Artemisia pollen season $(100 \%)$, two groups of sites could be distinguished: sites, where the threat for sensitive people is low, below $5 \%$ (Szczecin, Poznań, Wrocław, Łódź, Kraków) and the second group, where the threat is higher, over $5 \%$ (Sosnowiec, Rzeszów, Lublin) (Figs 3 and 6). 
Fig. 5 Time series of high Artemisia pollen concentrations $\left(\geq 30 \mathrm{PG} / \mathrm{m}^{3}\right)$ and Ambrosia pollen concentrations $(\geq 10 \mathrm{PG} /$ $\mathrm{m}^{3}$ ) in studied sites in selected years
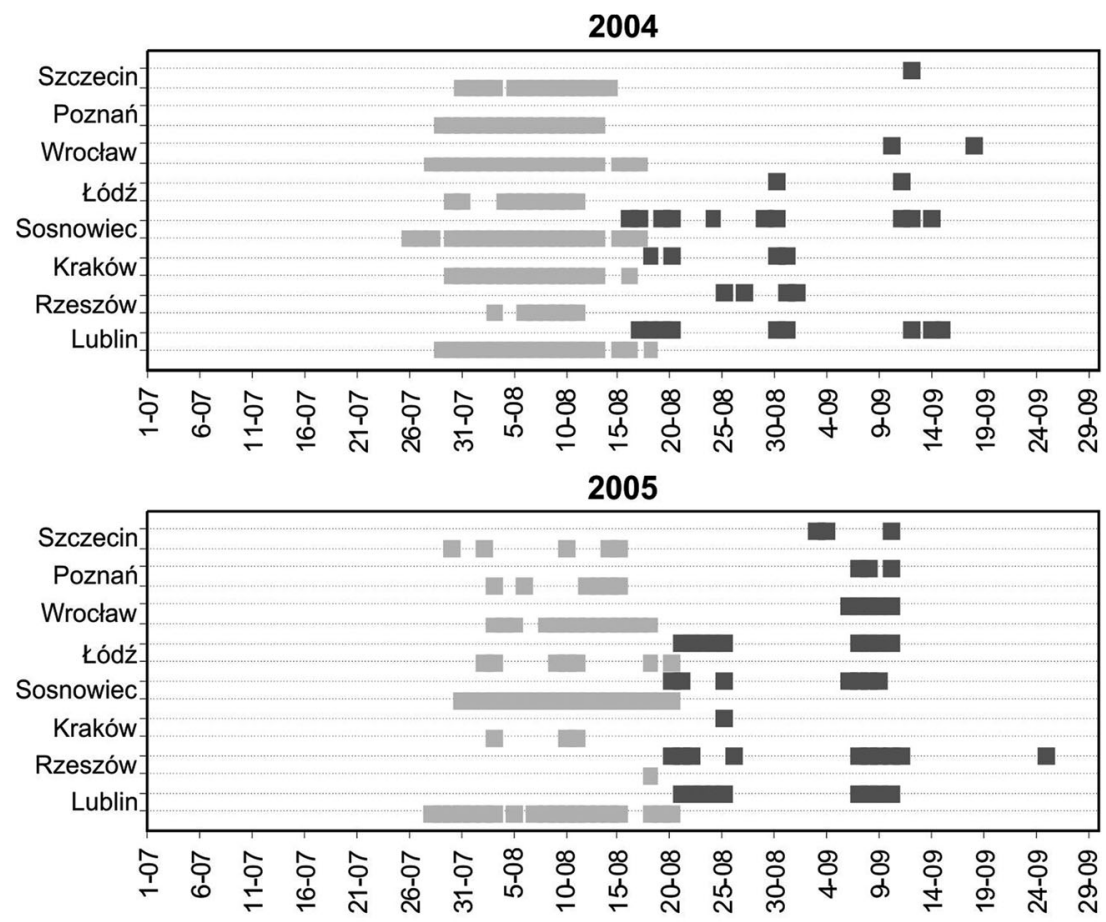

2008
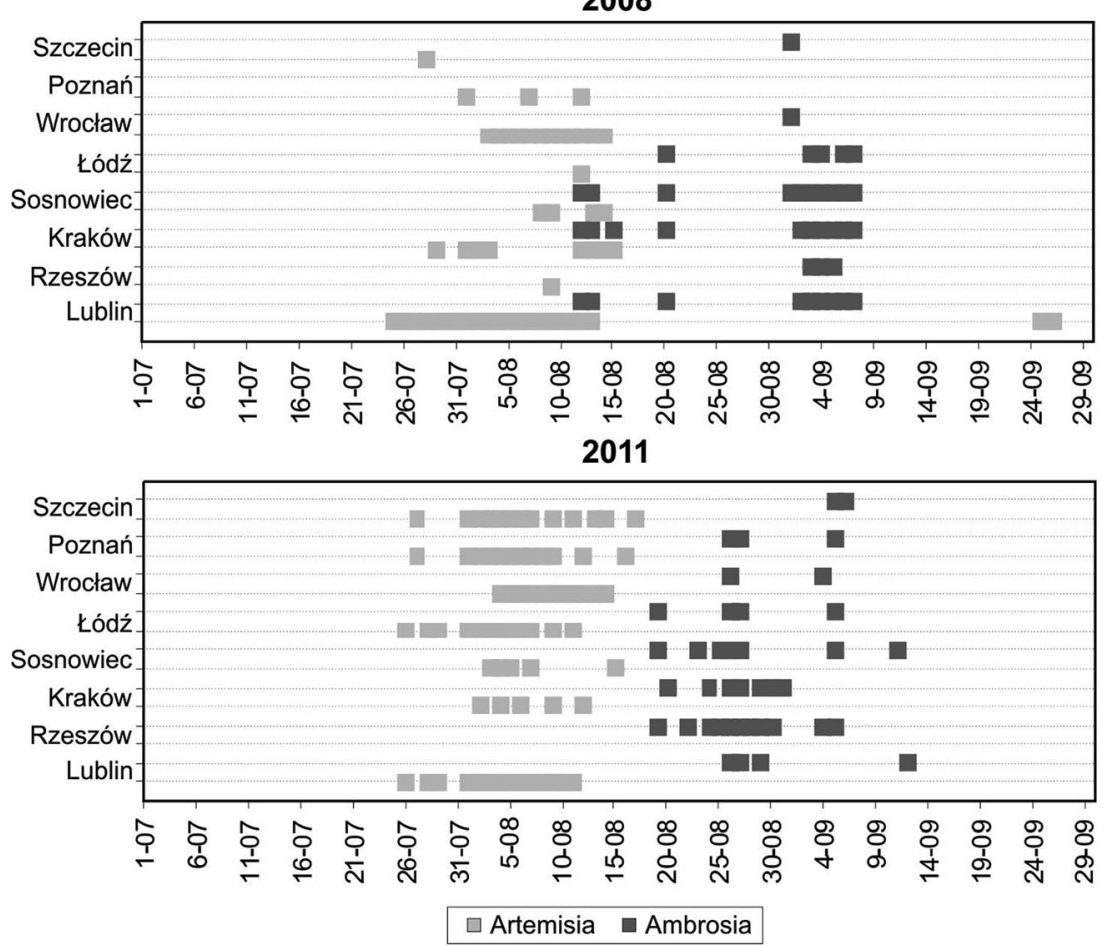

Days with high pollen concentration of both taxa in given synoptic situations

High Artemisia pollen concentrations were examined in relation to synoptic situations: with air circulation types in all the sites and also with air masses and atmospheric fronts in case of sites in the southern part of Poland (Sosnowiec, Kraków, Rzeszów, Lublin). Analysis of the frequency of days with high Artemisia pollen concentrations in different air circulation types indicates no clear relationship. High pollen concentrations $\left(\geq 30 \mathrm{PG} / \mathrm{m}^{3}\right)$ appeared with similar frequency $(10-20 \%)$ in no advection situation (central anticyclone situation - $\mathrm{Ca}$, anticyclonic wedge $-\mathrm{Ka}$, central cyclone situation $-\mathrm{Cc}$, through of low pressure $-\mathrm{Bc}$ ) and in other situations (Fig. 7). The relationship between high pollen concentration and air masses was more distinct. High pollen concentrations occurred when polar continental $(\mathrm{PPk})$ or polar maritime 

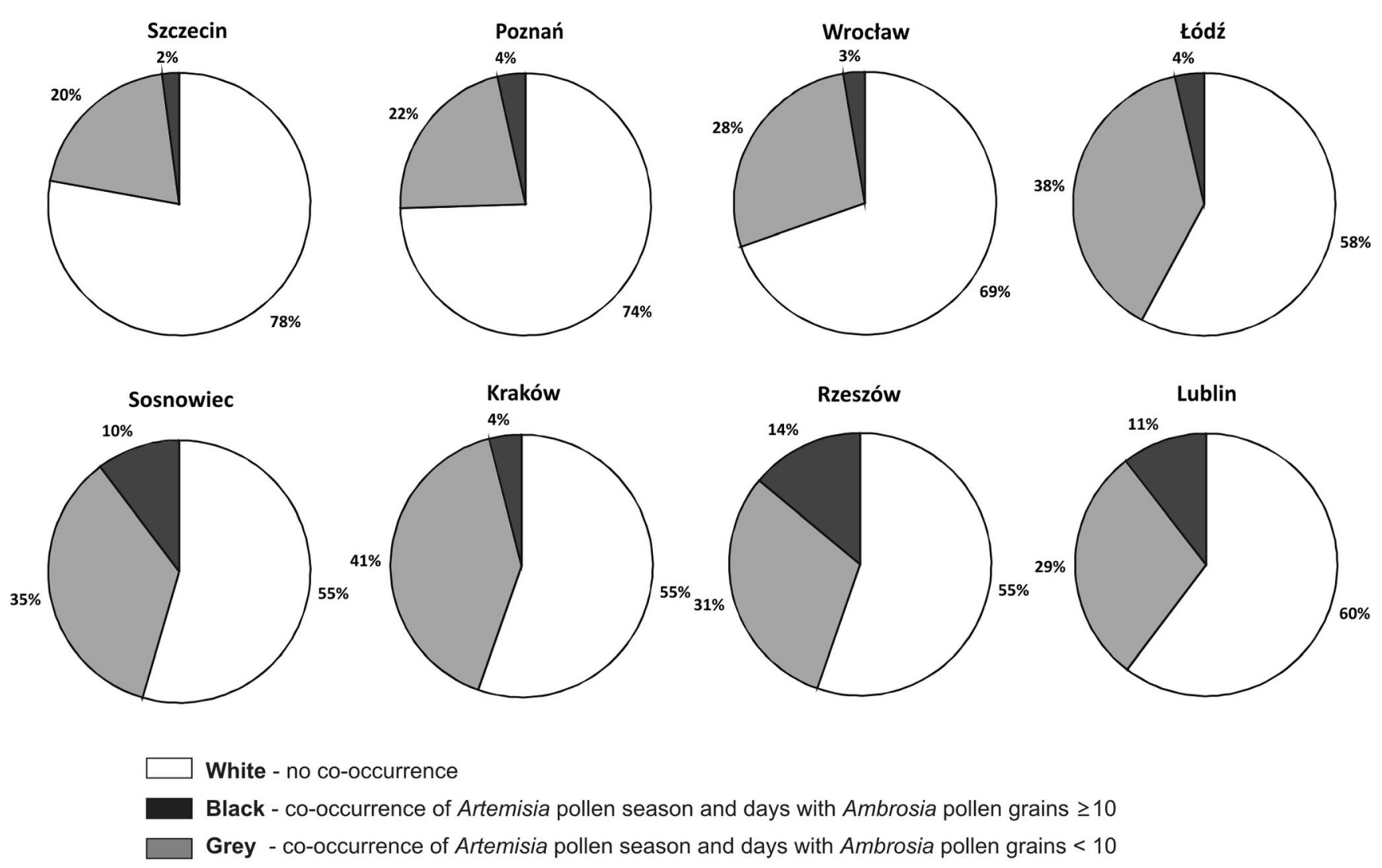

Fig. 6 Pie chart of Ambrosia pollen occurrence during the Artemisia pollen seasons, where the whole circle (100 \%) is the Artemisia pollen season

transformed (PPms) air masses were over the studied sites. These air masses bring warm, even hot and dry weather with no precipitation and no atmospheric fronts. For Szczecin, Poznań, Wrocław and Łódź it is difficult to point out a type of situation, that could be decisive for high Artemisia pollen concentration. In these sites pollen concentration in a given day seems to be dependent on the air masses rather than on the air circulation type. The increase in Artemisia pollen takes place when the weather is warm, dry, no precipitation. Such situation is provoked by polar continental or polar maritime transformed air masses.

The regressive trees (C\&RT) and analysis of frequency of days with high Ambrosia pollen concentrations $\left(\geq 10 \mathrm{PG} / \mathrm{m}^{3}\right.$ grains) showed results different than in the case of Artemisia. It was stated that in Rzeszów and Lublin days with high pollen concentrations occurred most often when southern Poland was influenced by low pressure, especially by central cyclonic $(\mathrm{Cc})$ or through of low pressure $(\mathrm{Bc})$ and cyclonic advection from south or south-west directions $(\mathrm{S}+\mathrm{SWc}$ ) (Fig. 8). In Sosnowiec and Kraków high pollen concentrations were associated mainly with air advection from south and south-west directions $(\mathrm{S}+\mathrm{SW})$ or east and south-east directions $(\mathrm{E}+\mathrm{SE})$ no matter what situation, cyclonic or anticyclone was. Generally high Ambrosia pollen concentrations accompanied polar continental (PPk) and polar maritime transformed (PPms) air masses, and in Kraków also tropical air masses advection (PZ). Days with high pollen concentrations occurred most often when no atmospheric fronts were present. In Wrocław and Łódź, similarly as in Sosnowiec and Kraków high Ambrosia pollen concentrations were associated with air advection from south and south-west directions $(\mathrm{S}+\mathrm{SWa}$ or $\mathrm{S}+\mathrm{SWc}$ ) no matter what situation, cyclonic or anticyclonic was. In Szczecin and Poznan the frequency of days with high pollen concentrations was similar to that in Rzeszów and Lublin, when low pressure dominated (Fig. 8).

\section{Discussion}

Analysis of Artemisia and Ambrosia pollen season characteristics revealed only two characteristics, a season start date and a day of maximum concentration with the low coefficient of variability for both taxa in all sites. Similar result, on the low coefficient of variability for the Ambrosia pollen season start, was given by Kasprzyk (2008). It could result from time during the year (July, August) when both taxa start their pollen seasons. Generally, the value of the coefficient of variability depends on thermal conditions that are more stable in later months of the year (Myszkowska et al. 2011). The pollen season start of early spring taxa e.g. Alnus and Corylus demonstrate the highest seasonal variability which depends on changeable thermal conditions at the beginning of the year (Kasprzyk et al. 2004; Rodriguez-Rajo et al. 2004). 


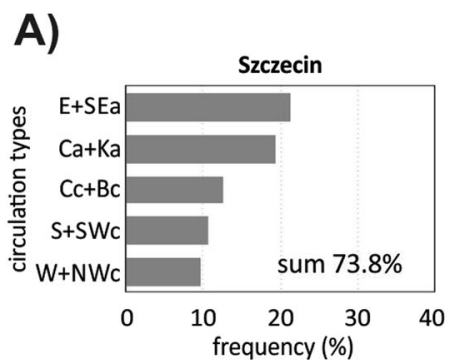

B)
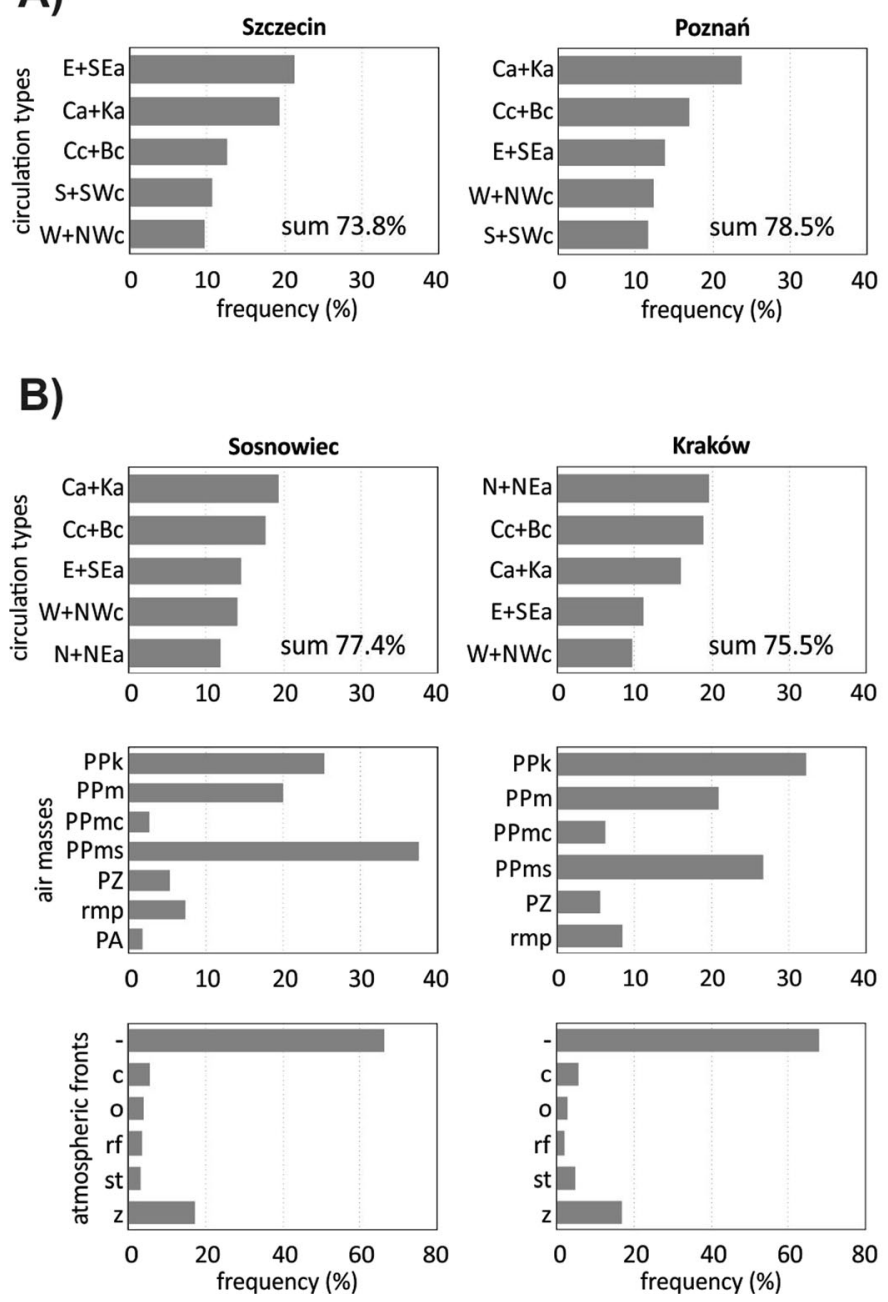
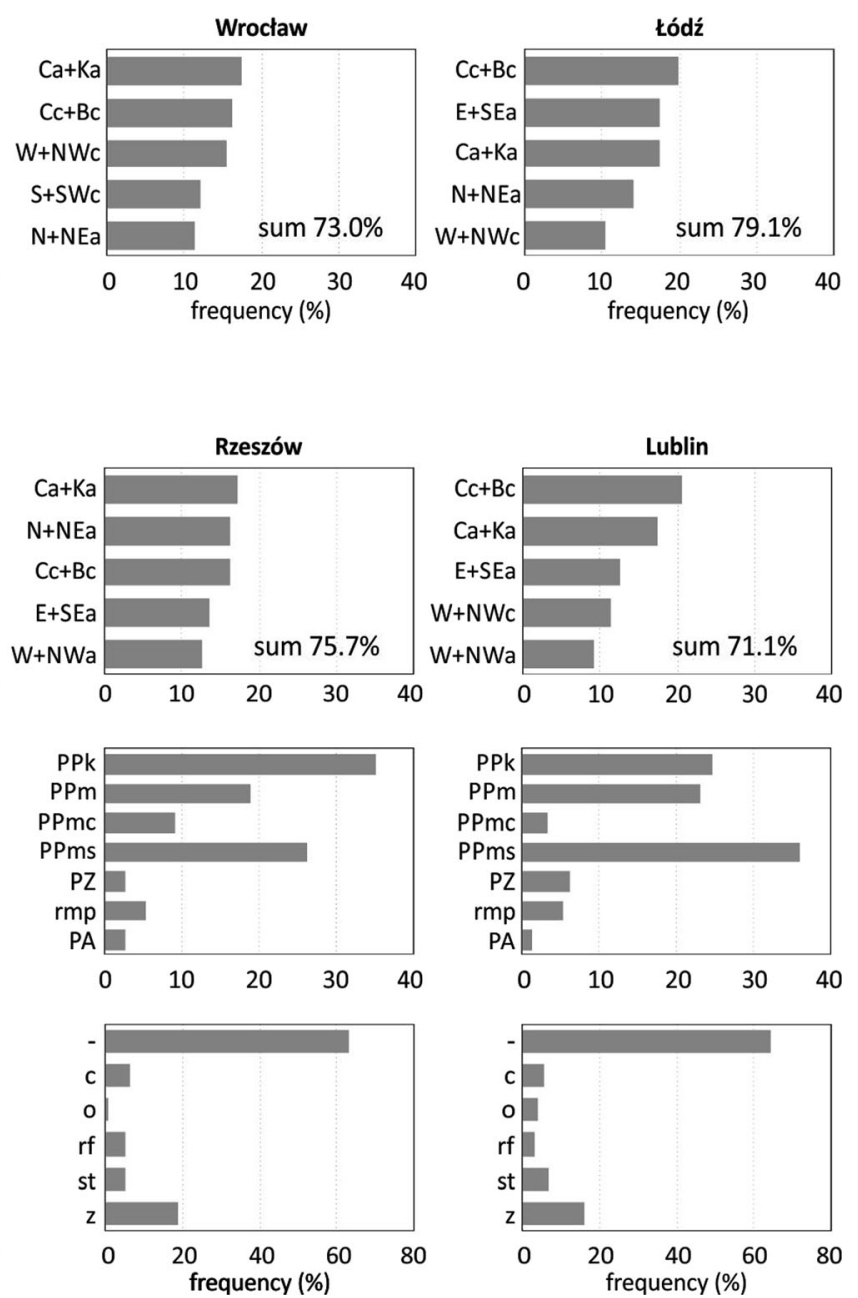

Fig. 7 Frequency of days with high Artemisia pollen concentrations $\left(\geq 30 \mathrm{PG} / \mathrm{m}^{3}\right)$ in studied sites in given synoptic situations: A - in air circulation types; B - in air circulation types, air masses, atmospheric fronts (according to Niedźwiedź, T., catalogue, 2015)

The pollen seasons of Artemisia begin, most often, in the second half of July at all the studied sites. Similar results were reported by Grewling et al. (2012) in their work on the variation of Artemisia pollen seasons in Central and Eastern Europe. They indicated that Artemisia pollen seasons generally occurred between the middle of July and September. These findings confirmed the earlier work by Spieksma et al. (1989), who stated that start dates did not vary very much at certain sites in Europe. Artemisia flowers in Central Europe at the end of July while in Mediterranean areas pollination occurs mainly in September. This delay results from releasing Artemisia pollen after the peak of summer temperature in the Mediterranean region or generally from the effect of rainfall, as even single day's rain, sharply stops the pollination within the main pollen season, or higher nutrient availability (Spieksma et al. 1989; D'Amato and Spieksma 1990). Puc (2006) noted the start of mugwort in the third decade of July, which agrees with our study. As regards the Ambrosia pollen season start, it is much more variable and dependent on site. On sites where the pollen season starts were least differentiated it could have resulted from local sources.

In contrast to the low variability found for the season start day and the day of maximum pollen concentration, the values of Ambrosia and Artemisia seasonal pollen index are the most variable season characteristics. Over consecutively studied years the values of Ambrosia SPI in Szczecin, Poznań, Wrocław, Łódź and Kraków were relatively similar and lower in comparison with Sosnowiec, Rzeszów and Lublin where higher pollen concentrations could result from a long distance transport. These findings coincide with reports by Chłopek and Tokarska-Guzik (2006), Malkiewicz and Wassowicz (2003), Piotrowska and WeryszkoChmielewska (2006), Puc (2004) and Stepalska et al. (2002). Ragweed pollen is one of the most abundant pollen type in the Pannonian Plain such as Croatia, where yearly total sums exceed 24,000 grains (Ivanić Grad) (Peternel et al. 2005), which is many times higher than in Polish sites.

Considering the spatial distribution of sites in Poland, statistically significant differences only occurred in the case of 
A)
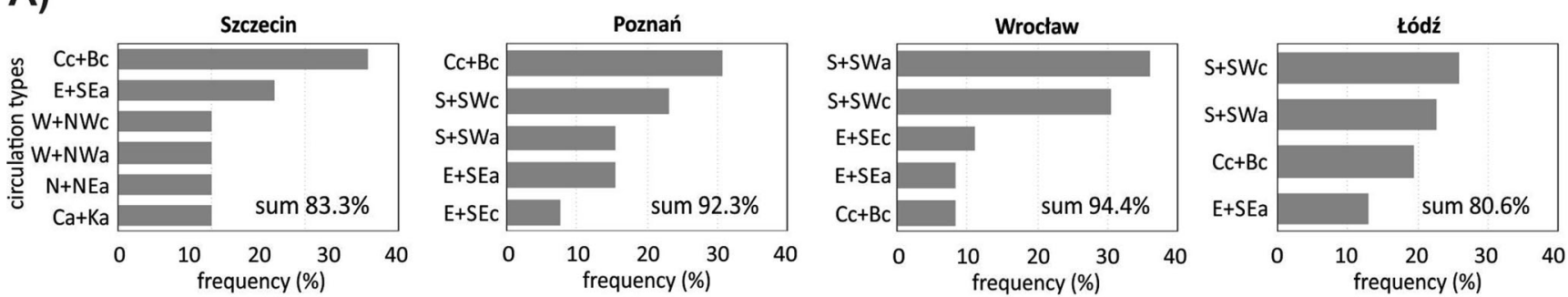

B)
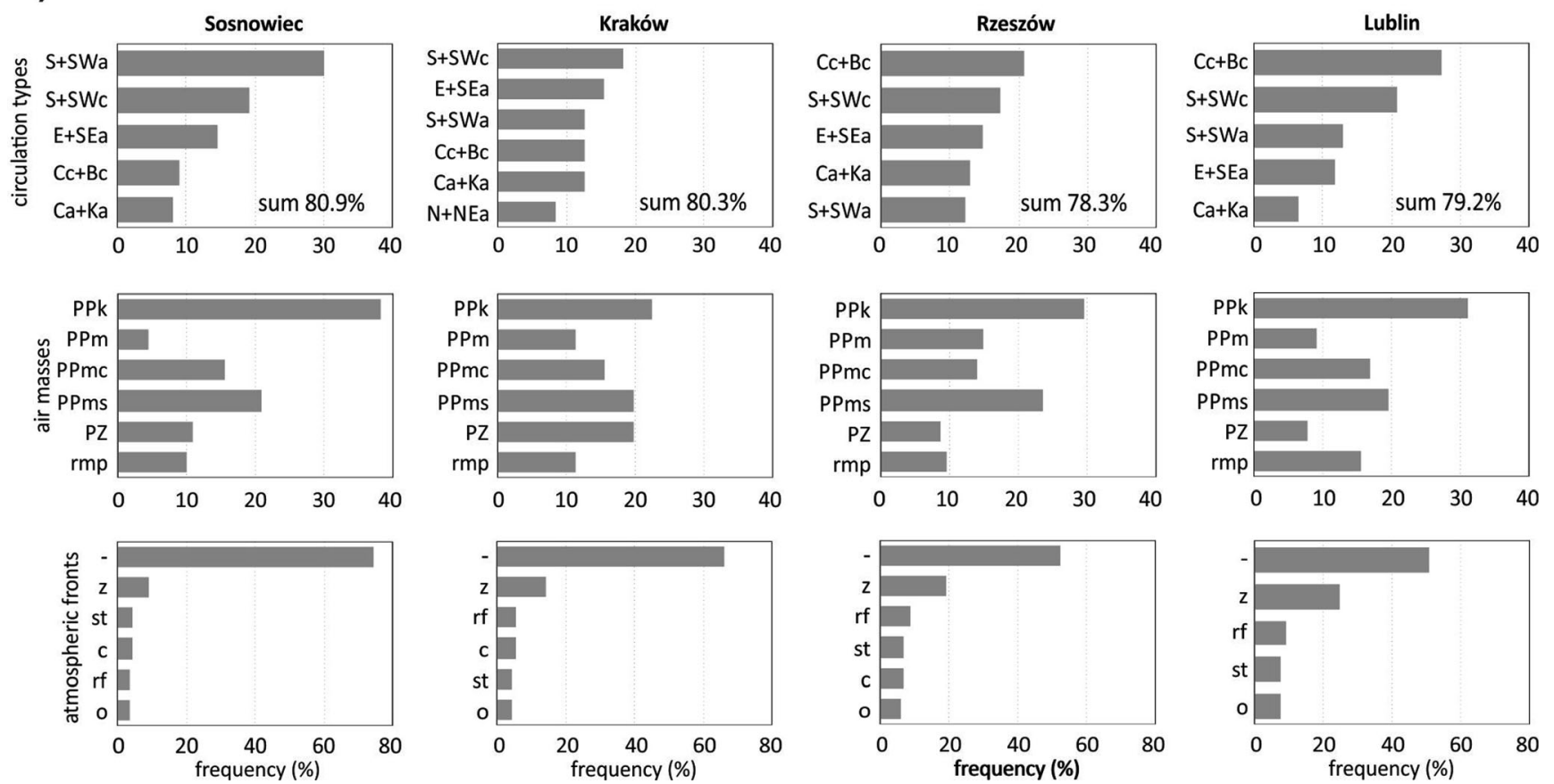

Fig. 8 Frequency of days with high Ambrosia pollen concentrations $\left(\geq 10 \mathrm{PG} / \mathrm{m}^{3}\right)$ in studied sites in given synoptic situations: A - in air circulation types; B - in air circulation types, air masses, atmospheric fronts (according to Niedźwiedź, T., catalogue, 2015)

Artemisia pollen season start dates and duration, while Ambrosia pollen season start dates and their durations only differed significantly at three sites in southern Poland. Differences in airborne pollen concentrations are due to variable wind directions and depend on the distance between the site of measurement and the source of emission (Emberlin and Norris-Hill 1991). Furthermore, the large-scale dispersion of atmospheric constituents is controlled by synoptic-, continental-, or hemispheric- scale meteorological phenomena (Sofiev et al. 2013). Pollen transport is affected by a combination of wind direction, wind speed and wind duration, assuming no major rainfall. Damialis et al. (2005) reported an important effect of the wind direction on airborne pollen concentrations, particularly in the case of numerous pollen sources lying in one direction. A similar dependence between pollen concentrations and the presence of pollinating taxa in the vicinity of the measurement site reported Arobba et al. (2000) in Genoa. In Szczecin high atmospheric pollen concentrations of ragweed and mugwort were recorded at the site in the vicinity of which there were numerous plants of these taxa (Puc 2006). Analyses of Artemisia pollen seasons in eight sites in Poland in 2001-2005 revealed the clear differences in annual pollen totals among sites and years (WeryszkoChmielewska et al. 2006).

Co-occurrence of pollen seasons of different taxa was reported earlier by only few papers. The phenomenon of cooccurrence is often considered as a result from extension of pollen seasons caused by gradual global warming and then there is possibility of overlapping. Pollen seasons of species flowering in summer have become longer. The end of Poaceae, Artemisia, Urtica and Ambrosia pollen seasons has tended to appear later (Wan et al. 2002). The comparison of Artemisia and Ambrosia pollen seasonal dynamics in Cracow, Poland shows, that there is possibility of the high pollen concentration occurrence of both taxa simultaneously, in the second part of August (late summer). This could be the reason for the increase in allergy symptoms resulting from a crossreaction between allergens of both taxa (Myszkowska et al. 
2012). Moreover, in the case of the late summer pollinating plants (Artemisia and Ambrosia), the negative correlation between pollen season start and end was found, the later pollen season starts, the earlier pollen season ends (Myszkowska et al. 2011).

In aerobiological literature it is stressed that increased temperature during summer and early autumn could cause the increasing growth of Ambrosia plants, and increasing pollen production; and this phenomenon is associated often with the higher concentration of $\mathrm{CO}_{2}$ in the air (Smith et al. 2013 and references therein). Barnes et al. (2001) stated that temperature and relative humidity slightly influence daily Ambrosia pollen concentrations but passing cold fronts have the greatest effect on airborne Ambrosia pollen concentrations. According to studies on phenological phases it is stated that the length of the pollen season becomes extended in plants flowering in summer (Huynen et al. 2003) that could result in co-occurrence of different species.

According to our present results, cnalysis of Artemisia pollen concentrations against a background of synoptic situation revealed that there is no clear relationship between frequency of days with high pollen concentrations in different air circulation types. However, the relationship between high pollen concentration and air masses was sharply outlined. High pollen concentrations occurred when polar continental (PPk) from the east or polar maritime transformed (PPms) air masses from the west were over the studied sites which suggests the case of the regional transport and sporadically long-distance transport. Long distance transport (LDT) episodes of airborne pollen are usually irregular (Smith et al. 2008) and can modify the characteristics of the pollen season (Sofiev et al. 2006). LDT episodes have been earlier identified for Ambrosia (Sikoparija et al. 2009; Stach et al. 2007), Artemisia (Izquierdo et al. 2011) and Betula (Skjøth et al. 2007).

In Budapest, Hungary, significant differences might be found in Ambrosia pollen concentrations on days with different weather types. Most of the anticyclonic situations are favourable for pollination, and all cyclonic situations are unfavourable. However, a part of the anticyclonic types were also unfavourable (Fehér and Járai-Komlódi 1996). Analysis of wind directions occurring the most often in Cracow showed Ambrosia pollen concentrations associated to wind blowing from easterly (E) and east-southeasterly (ESE) directions which indicated the long distance transport from the Czech Republic, Slovakia, Hungary and Ukraine. Wind from westerly (W) and west southwesterly (WSW) directions could have brought pollen from local sources in the western part of Poland (Stępalska et al. 2008). Kasprzyk (2008) noted high airborne Ambrosia pollen concentrations recorded on days when air mass advection came from east and south east, and from south and south-west. On days with polar maritime or arctic air masses, pollen concentrations were statistically significantly lower than on days with polar continental, polar maritime warm and polar maritime transformed air masses.
The study performed in Sosnowiec, Poland on the threat of Ambrosia pollen at a regional scale showed a high negative correlation between frequency of air masses (polar maritime) from the west and the annual sum of pollen grains and maximum daily concentration (Chłopek et al. 2011). Hot and dry weather on the Pannonian Plain (PP) favours the release Ambrosia pollen during the flowering season. Adequate synoptic situations are required for air masses bearing pollen to move northward causing LDT from the PP to Poland and further into Scandinavia (Šikoparija et al. 2013).

\section{Conclusions}

1. The Artemisia pollen seasons most often start in the second half of July at all the sites, while Ambrosia pollen seasons starts are much more variable.

2. Season start dates and dates of maximum concentration for Artemisia and Ambrosia show the lowestcoefficient of variability.

3. Pollen seasons of both taxa could overlap at all the sites although not every year. In Lublin and Rzeszów (100\% each site), and in Łódź ( $90 \%$ ) the co-occurrence of both taxa pollen seasons is the highest, while in Szczecin (62\%), Poznan (60\%), and Wroclaw (55\%) is the lowest.

4. In south-eastern Poland (Sosnowiec, Rzeszów, Lublin) high Ambrosia pollen concentrations during the Artemisia pollen season appear more often than in other study sites. It is, on the average, $3-5$ days in a year.

5. High Artemisia pollen concentrations occur when polar continental (PPk) air masses inflow into Poland from the east or when polar maritime transformed (PPms) air masses come from the west.

6. In case of Ambrosia, days with high pollen concentrations occurred most often when sites under question were affected by low pressure and cyclonic advection from south or south-west directions (Szczecin, Poznań, Rzeszów, Lublin) or high pollen concentrations were associated mainly with air advection from south and south-west directions or east and south-east directions irrespective of cyclonic or anticyclonic situation (Wrocław, Łódź, Sosnowiec, Kraków).

7. Co-occurrence of pollen seasons of both taxa depends on the type of atmospheric circulation.

Acknowledgments The results presented here address some aspects described in the COST Action Smarter, especially in the Work Group 4 related to the Asteraceae family (Artemisia, Ambrosia) which intensify human health risk.

Open Access This article is distributed under the terms of the Creative Commons Attribution 4.0 International License (http:// creativecommons.org/licenses/by/4.0/), which permits unrestricted use, distribution, and reproduction in any medium, provided you give appropriate credit to the original author(s) and the source, provide a link to the Creative Commons license, and indicate if changes were made. 


\section{References}

Arobba D, Guido MA, Minale P, Montanari C, Placereani S, Pracilio S, Troise C, Voltolini S, Negrini AC (2000) Airborne pollen in genoa (NW-Italy): a comparison between two pollen-sampling stations. Aerobiologia 16:233-243

Asero R (2002) Birch and ragweed pollinosis north of Milan: a model to investigate the effects of exposure to "new" airborne allergens. Allergy 57:1063-1066

Asero R, Wopfner N, Gruber P, Gadermaier W, Ferreira F (2006) Artemisia and Ambrosia hypersensitivity: co-sensitization or co-recognition? Clin Exp Allergy 36:658-665

Barnes C, Pacheco F, Landuyt J, Hu F, Portnoy J (2001) The effect of temperature, relative humidity and rainfall on airborne. Aerobiologia 17:61-68

Chłopek K, Tokarska-Guzik B (2006) Pyłek ambrozji (Ambrosia) w aeroplanktonie Górnego Ślaska. Acta Agrobot 59(1):335-324

Chłopek K, Dąbrowska-Zapart K, Tokarska-Guzik B (2011) An assessment of the Ambrosia pollen threat at a regional scale using the example of the town of Sosnowiec (Silesian uplands, Poland). Acta Agrobot 64(2):51-62

Clot B (2003) Trends in airborne pollen: an overview of 21 years of data in Neuchâtel (Switzerland). Aerobiologia 19:227-234

Comtois P (1998) Ragweed (Ambrosia sp.): the Phoenix of allergophytes. 6th International Congress on Aerobiology. Satellite Symposium Proceedings: Ragweed in Europe, Perugia, Italy, ALK Abelló. 3-5

Comtois P, Gagnon L (1998) Concentration pollinique et fréquence des symptoms de pollinose: une méthod pour determiner les seuils cliniques. Rev Fr Allergol 28(4):279-286

Dahl A, Strandhede SO, Wihl JA (1999) Ragweed - an allergy risk in Sweden? Allergologia 15:67-70

D’Amato D, Spieksma FTM (1990) Allergenic pollen in Europe. Grana 30:67-70

D'Amato D, Spieksma FTM, Liccardi G, Jäger S, Russo M, Kontou-Fili K, Nikkels H, Wüthrich B, Bonini S (1998) Pollen-related allergy in Europe. Allergy 53(6):567-578

D'Amato D, Cecchi L, Bonini S, Nunes C, Annesi-Maesano I, Behrendt $\mathrm{H}$ et al (2007) Allergenic pollen and pollen allergy in Europe. Allergy 62(9):976-990

Damialis A, Gioulekas D, Laopoulou C, Balafontis C, Vokou D (2005) Transport of airborne pollen into the city of Thessaloniki: the effects of wind direction, speed and persistence. Int J Biometeorol 49:139 145

Dechamp C, Rimet ML, Meon H, Deviller P (1997) Parameters of ragweed pollination in the Lyon's area (France) from 14 years of pollen counts. Aerobiologia 13:275-279

Dynowska I (1991) Obieg wody (Hydrogeography). In: Starkel L(ed) Geografia Polski. Środowisko Przyrodnicze (Geography of Poland. Natural Resources), PWN, Warszawa, pp 355-387 (in Polish)

Emberlin J, Norris-Hill J (1991) Spatial variation of pollen deposition in North London. Grana 30:190-195

Fehér Z, Járai-Komlódi M (1996) Relationship between air borne ragweed pollen concentration and the macrosynoptic weather types in Budapest, Hungary. Ann Agric Environ Med 3:121-126

Gadermaier G, Dedic A, Obermeyer G, Frank S, Himly M, Ferreira F (2004) Biology of weed pollen allergens. Current Allergy and Asthma Reports 4:391-400

Grewling Ł, Sikoparija B, Skjøth CA, Radisic P, Apatini D, Magyar D et al (2012) Variation in Artemisia pollen seasons in central and Eastern Europe. Agric For Meteorol 160:48-59

Hansen A (1976) Ambrosia L. In: Tutin TG, Heywood NA, Burges DM, Moore DH, Valentine SM, Walters DA Webb (eds) Flora Europea. Cambridge Univ Press, Cambridge/London/New York/Melbourne pp 142-143
Hirschwehr R, Heppner C, Spitzauer S, Speer WR, Valent P, Berger U et al (1998) Identification of common allergenic structures in mugwort and ragweed. J Allergy Clin Immunol 101:196-206

Hirst JM (1952) An automatic spore trap. Ann Appl Biol 39:257-265

Huynen M, Menne B, Behrendt H, Bertollini R, Bonini S, Brandao R et al (2003) Phenology and human health: allergic disorders. Health and Global Environmental Change, Rome

Izquierdo R, Belmonte J, Avila A, Alarcón M, Cuevas E, Alonso-Pérez S (2011) Source areas and long-range transport of pollen from continental land to Tenerife (Canary Islands. Int J Biometeorol 55:67-85

Jäger S (1998) Global aspects of ragweed in Europe. 6th International Congress on Aerobiology. Satellite Symposium Proceedings: Ragweed in Europe, Perugia, Italy, ALK Abelló 6-10

Jäger S (2000) Ragweed (Ambrosia) sensitisation rates correlate with the amount of inhaled airborne pollen. A 14-year study in Vienna, Austria. Aerobiologia 16:149-153

Jäger S, Litschauer R (1998) Ragweed (Ambrosia) in Austria. 6th International Congress on Aerobiology. Satellite Symposium Proceedings: Ragweed in Europe, Perugia, Italy, ALK Abelló 22-26

Járai-Komlódi M, Juhász M (1993) Ambrosia elatior (L). In Hungary (1989-1990. Aerobiologia 9:75-78

Juhász M (1998) History of ragweed in Europe. 6th International Congress on Aerobiology. Satellite Symposium Proceedings: Ragweed in Europe, Perugia, Italy, ALK Abelló 11-14

Kasprzyk I (2008) Non-native Ambrosia pollen in the atmosphere of Rzeszów (SE Poland); evaluation of the effect of weather conditions on daily concentrations and starting dates of the pollen season. Int J Biometeorol 52(5):341-351

Kasprzyk I, Uruska A, Szczepanek K, Latałowa M, Gaweł J, Harmata K et al (2004) Regional differentiation of the dynamics of the pollen seasons of Alnus, Corylus, Fraxinus in Poland (preliminary results. Aerobiologia 20:141-151

Kożuchowski K (1999) Klimat Polski. Nowe spojrzenie. (Climate of Polish. New insight), PWN, Warszawa pp 293 (in Polish)

Laaidi K, Laaidi M (1999) Airborne pollen of Ambrosia in burgundy (France) 1996-1997. Aerobiologia 15:65-69

Makra L, Juhász M, Béczi R, Borsos E (2005) The history and impacts of airborne Ambrosia (Asteraceae) pollen in Hungary. Grana 44:57-64

Malkiewicz M, Wasowicz A (2003) Ambrosia pollen grains in aeroplankton of Wrocław. Ann Univ Mariae Curie Skłodowska Sec Hortic EEE 13:333-339

Myszkowska D, Jenner B, Stępalska D, Czarnobilska E (2011) The pollen season dynamics and the relationship among some season parameters (start, end, annual total, season phases) in Kraków, Poland, 1991-2008. Aerobiologia 27(3):229-238

Myszkowska D, Stępalska D, Dyga W, Bokalska-Rajba J, Czarnobilska E (2012) Survey of biological particles in the atmosphere of the Cracow center (southern Poland) in 2011. Preliminary study. Przegląd Lekarski 69(12):1254-1260

Niedźwiedź T (2006) Typologia cyrkulacji atmosfery dla Polski i metody określania regionalnych wskaźników cyrkulacji (typology of circulation for Poland and the methods of calculations of the regional circulation indices). Annales UMCS 38:326-335 in Polish

Niedźwiedź T (2015) Kalendarz typów cyrkulacji atmosfery dla Polski południowej-zbiór komputerowy (Calendar of circulation types for teritory of Southern Poland. Uniwersytet Śląski, Katedra Klimatologii, Sosnowiec. klimat.wnoz.us.edu.pl

Nilsson S, Persson S (1981) Tree pollen spectra in the Stockholm region (Sweden), 1973-1980. Grana 20:179-182

Paszyński J, Niedźwiedź T (1991) Klimat. (Climate). In: Starkel L ed. Geografia Polski. Środowisko przyrodnicze. (Geography of Poland. Natural Resources), PWN, Warszawa pp 296-355 (in Polish)

Peternel R, Culig J, Srnec L, Mitic B, Vucusic I, Hgra I (2005) Variation in ragweed (Ambrosia artemisiifolia L.) pollen concentration in Central Croatia, 2002-2003. Ann Agric Environ Med 12:11-16 
Peternel R, Milanovic SM, Srnec L (2008) Airborne ragweed (Ambrosia artemisiifolia L.) pollen content in the city of Zagreb and implications on pollen allergy. Ann Agric Environ Med 15(1):125-130

Piotrowska K, Weryszko-Chmielewska E (2006) Ambrosia pollen in the air of Lublin, Poland. Aerobiologia 2:151-158

Puc M (2004) Ragweed pollen in the air of Szczecin. Ann Agric Environ Med 11:53-57

Puc (2006) Ragweed and mugwort pollen in Szczecin, Poland. Aerobiologia 22:67-78

Rapiejko P, Stankiewicz W, Szczygielski K, Jurkiewicz D (2007) Threshold pollen count necessary to evoke allergic symptoms. Otolaryngologia Polska LXI:591-594

Rodriguez-Rajo FJ, Dopazo A, Jato V (2004) Environmental factors affecting the start of pollen season and concentrations of airborne Alnus pollen in two localities of Galicia (NW Spain. Ann Agric Environ Med 11:35-44

Saar M, Gudžinskas G, Ploompuu T, Linno E, Minkiene Z, Motiekaityte V (2000) Ragweed plants and airborne pollen in the Baltic states. Aerobiologia 16:101-106

Šikoparija B, Smith M, Skjøth CA, Radišić R, Milkovska S, Šimić S et al (2009) The Pannonian plain as a source of Ambrosia pollen in the Balkans. Int J Biometeorol 53:263-272

Šikoparija B, Skjøth CA, Kübler A, Dahl A, Sommer J, Grewling $Ł$ et al (2013) A mechanism for long distance transport of Ambrosia pollen from the Pannonian plain. Agric For Meteorol 180:112-117

Skjøth CA, Sommer J, Stach A, Smith M, Brandt J (2007) The longdistance transport of birch (Betula) pollen from Poland and Germany causes significant pre-season concentrations in Denmark. Clin Exp Allergy 37:1204-1212

Smith M, Skjøth CA, Myszkowska D, Uruska A, Puc M, Stach A (2008) Long-range transport of Ambrosia pollen to Poland. Agric For Meteorol 148:1402-1411

Smith M, Cecchi L, Skjøth CA, Karrer G, Šikoparija B (2013) Common ragweed: a threat to environmental health in Europe. Environ Int 61:115-126

Sofiev M, Siljamo P, Ranta H, Rantio-Lehtimäki A (2006) Towards numerical forecasting of long-range transport of birch pollen: theoretical considerations and a feasibility study. Int J Biometeorol 50:392-402

Sofiev M, Belmonte J, Gehrig R, Izquierdo R, Smith M, Dahl A, Siljamo P (2013) Airborne pollen transport. In: Sofiev M, Bergmann K-C (eds) Allergenic pollen. A review of the production, release, distribution and health impacts. Springer, Dordrecht, Heidelberg, New York, London, pp. 127-159

Soó R (1970) A Magyar Flóra és vegetáció rendszertani növényföldrajzi kézikönyve IV. Akadémiai kiadó, Budapest

Spieksma FTM (1986) Airborne pollen concentrations in Leiden, the Netherlands, 1977-1981. III. Herbs and weeds flowering in the summer. Grana 25:47-54
Spieksma FTM, Frenguelli G, Nikkels AH, Mincigrucci G, Smithius LOM, Bricchi E et al (1989) Comparative study of airborne pollen concentrations in Central Italy and the Netherlands: emphasis on Alnus, Poaceae, and Artemisia. Grana 28:25-36

Spieksma FTM, Corden JM, Detandt M, Millington WM, Nikkels H, Nolard N et al (2003) Quantitive trends in annual totals of five common airborne pollen types (Betula, Quercus, Poaceae, Urtica, and Artemisia), at five pollen-monitoring stations in western Europe. Aerobiologia 19:171-184

Stach A, Garcia-Mozo H, Prieto-Baena JC, Czarnecka-Operacz M, Jenerowicz D, Silny W et al (2007) Prevalence of Artemisia species pollinosis in western Poland: impact of climatic change on aerobiological trends, 1995-2004. J Investig Allergol Clin Immunol 17(1): 39-47

Stępalska D, Szczepanek K, Myszkowska D (2002) Variation in Ambrosia pollen concentration in southern and Central Poland 1982-1999. Aerobiologia 18:13-22

Stepalska D, Myszkowska D, Wołek J, Piotrowicz K, Obtułowicz K (2008) The influence of meteorological factors on Ambrosia pollen loads in Cracow, Poland, 1995-2006. Grana 47:297-304

Tokarska-Guzik B, Bzdega K, Koszela K, Żabińska I, Krztuś B, Sajan M et al (2011) Allergenic invasive plant Ambrosia artemisiifolia L. In Poland: threat and selected aspects of biology. Biodivers Res Conserv 21:39-48

Tutin TG. (1972) Artemisia L. In: Tutin TG, Heywood NA, Burges DM, Moore DH, Valentine SM, Walters DA Webb eds. Flora Europea IV. Cambridge, Cambridge University Press pp 78-186

Voltolini S, Minale P, Troise C, Bignardi D, Modena P, Arobba D et al (2000) Trend of herbaceous pollen diffusion and allergic sensitization in genoa, Italy. Aerobiologia 16:245-249

Wan S, Yuan T, Bowdish S, Wallace L, Russel SD, Luo Y (2002) Response of an allergenic species, Ambrosia psilostachya (Asteraceae), to experimental warming and clipping: implications for public health. Am J Bot 89:1843-1846

Weryszko-Chmielewska E, Piotrowska K (2008) Ecological features of Ambrosia artemisiifolia L. Flowers and characteristics of Ambrosia L. Pollen seasons in the condition of Lublin (Poland) in the years 2001-2008. Acta Agrobot 61(2):35-47

Weryszko-Chmielewska E, Piotrowska K, Chłopek K, Kasprzyk I, Malkiewicz M, Myszkowska D, et al. (2006) Analiza sezonów pyłkowych bylicy (Artemisia L.) w wybranych miastach Polski w latach 2001-2005 (Analysis of pollen seasons of mugwort (Artemisia L.) in selected cities in Poland in 2001-2005. In: Weryszko-Chmielewska E ed. Pyłek roślin w aeroplanktonie różnych regionów Polski (Pollen of plants in aeroplankton of different regions of Poland), Lublin pp 133-141 (in Polish)

Zajac A, Zajac M (2001) Distribution atlas of vascular plants in Poland, 1st edn. Laboratory of Computer Chorology, Institute of Botany, Jagiellonian University and Foundation of Jagiellonian University, Krakow 